\title{
PREDICTABILITY OF ROUND WEIGHT BY SOME BODY MEASUREMENTS, AGE AND ULTRASOUND MEASUREMENTS IN AUBRAC AND CHAROLAIS FATTENING BULLS
}

\author{
J. Tőzser ${ }^{1}$, A. Szentléleki ${ }^{1}$, Z. Domokos ${ }^{2}$, R. Verténé Zándoki ${ }^{1}$, C. $_{\text {Bottura }}{ }^{3}$, M. Alberti ${ }^{3}$, \\ and A.S. Khattab ${ }^{4}$
}

1- Institute of Animal Husbandry, Szent Istvá University, H-2103 Cödöllö, Páter K. U. 1., Hungary, 2- Association of Hungarian Charolais Breeders, 3525 Miskolc, Vologda str. 3- La Garonnaise Ltd., 3773 Sajólászlófalva, 4- Department of Animal Production, Faculty of Agriculture, University of Tanta, Egypt

\section{SUMMARY}

Authors' aim was to find factors determining round weight in Aubrac $(n=18)$ and Charolais $(n=8)$ fattening bulls. Experiments were carried out in 2007, at Italian fattening farm ( $n=26$, live age (LA): $570 \pm 6.41$ days, live weight $(L W): 621 \pm 60.76 \mathrm{~kg}$ ). The main body measurements (height at withers (HW), height at rump (HR), chest girth (CG) and slanting body length (SBL)) were measured. Ultrasound images of rib eye area (REA) and rump fat thickness (P8) were taken with Falco 100 Pie Medical ultrasound equipment. The mean values of body measurements were as follows: HW: 122.9 cm, HR: $130.5 \mathrm{~cm}$; CG: $201.9 \mathrm{~cm}$, SBL: $149.1 \mathrm{~cm}$. REA, P8 and weight of round were $96.2 \mathrm{~cm}^{2}, 0.70$ $\mathrm{cm}$ and $133.5 \mathrm{~kg}$, respectively. Correlations between $L W$ and the different body measurements were: HW: $r=0.57(P<0.001), H R: r=0.55(P<0.01), C G: r=0.60(P<0.001), S B L: r=0.18$. A very close correlation was revealed between $L W$ and weight of round $(r=0.93, P<0.001)$. Stepwise regression analysis (backward method) was used to examine how the weight of round $(y)$ is affected by LA $\left(x_{1}\right)$, $H W\left(x_{2}\right), H R\left(x_{3}\right), C G\left(x_{4}\right), S B L\left(x_{5}\right), R E A\left(x_{6}\right)$ and P8 $\left(x_{7}\right)$. In the $1^{\text {st }}$ of the 7 models all parameters existed as independent variables, multiple correlation coefficient $(R)$ was $0.70\left(P<0.10, r_{\text {sxy }}=11.65\right.$ $\mathrm{kg}$ ). In the $4^{\text {th }}$ model, $L A, H W, C G$ and REA remained as independent variables, resulting an $R$ value similar to that of the $1^{\text {st }}$ model $\left(R=0.69, P<0.01, r_{\text {sxy }}=10.88 \mathrm{~kg}\right)$. The last model contained only $C G$ $\left(R=0.62, P<0.001, r_{\text {sxy }}=11.11 \mathrm{~kg}\right)$. It was confirmed that the weight of round was determined in $38 \%$ only by CG. It seems to be worth combining some body measurements with LA and ultrasound REA results for in vivo estimation of round weight of fattening bulls.

Keywords: Aubrac and Charolais, fattening bulls, body measurements, ultrasound images, prediction

\section{INTRODUCTION}

Since the domestication of cattle, an important aim of breeding has always been the improvement of beef production traits. Although the number of beef type herds is growing all around the world, the main part of beef is produced by dairy animals.

Nowadays, in selection programs of beef cattle, slaughter- and beef quality traits have been becoming more and more important. The reason for this is the changing demand by customers towards beef quality preferring lean meat.

It is widely known that slaughtering value of cattle is determined by quantity and quality traits of carcass, out of which the tissue composition, meat-bone-fat ratio and quantity are the most important. This can be evaluated well by slaughter trial. Slaughtered, and boning is a hard work that does not fit easily in the usual slaughterhouse technology. That is why it has become an aim of breeders to work out methods for examining body composition of live breeding and fattening animals and carcasses without boning.

Many methods have been developed, but their adaptability in practice and accuracy of prediction are different. Generally applied methods of evaluating an animal's traits in vivo are type classification and body condition scoring which are more or less involved in selection programs of most beef breeds. Experiments show that in evaluation of different cattle types, taking body measurements is also useful. Results from Hungarian authors concerning body measurements and body conformation indices are summarised as (1) Growth speed of different body measurements (Bartosiewicz et al.,1987), (2) Evaluation of body measurements and body conformation in performance tests (Tözsér et al. ,1995 and Polgár and Szabó, 1997), (3) Body measurements and body measurement ratios of cows from different breeds ( Nagy et al. 2007) and Body measurements and body measurement ratios of weaned calves and 
fattened cattle ( Szabó et al. ;1993 and Tőzsér et al. ,1998) .

In the last decade, image analysing techniques (ultrasound, Rontgen-beam, magnetic resonance) were experienced and introduced in practice of cattle breeding (Holló, 2001). Ultrasound measurements were first taken in domestic animals, - for the first time in cattle - by Temple et al. (1956), and Claus (1957). Since then, many researchers have advised the use of ultrasound equipment in practice of beef cattle breeding and fattening, to determine optimal date for end off fattening period and to predict carcass yield (Robinson et al., 1993, Herring et al., 1994, Wilson et al., 2000).In the same time, attention was drawn to importance of experienced technicians and technical requirements. Details are not described in this article since they were introduced in an earlier study (Holló et al., 2005). Results of international research (i.e., Simm et al., 1983; Miller et al., 1988; Waldner et al., 1992; Hassen et al., 1999 and Wolcott, 2003) show that regression models containing ultrasound measurement results combined with different other traits, although with different determination coefficients $\left(\mathrm{R}^{2}\right)$, are appropriate to predict carcass composition (e.g. lean meat $\%$, marketable meat $\%$, protein content between ribs 9-11, etc., and ranged from 0.56 to 0.83 ).

Aim of the present study was to estimate how age, body measurements (height at withers, hip height, chest circumference, and diagonal body length) and ultrasound measurement results of rib eye area and rump fat thickness (P8) affect round weight of Charolais and Aubrac fattening bulls.

\section{MATERIALS AND METHODS}

\section{Source of data and management :}

A part of the experiment was carried out in February, 2007 by Institute of Animal Breeding, Szent István University and Hungarian Association of Charolais Breeders on 18 Aubrac (age: 570 \pm 5.91 days, live weight: $609.2 \pm 66.70 \mathrm{~kg}$ ) and 8 Charolais (age: $568 \pm 7.57$ days, live weight: $647.5 \pm 34.96 \mathrm{~kg}$ ) fattening bulls in Italy. Age and live weight at end of fattening was $570 \pm 6.41$ days and $621 \pm 60.76 \mathrm{~kg}$ for the two groups, respectively. Feeding system of the two groups was the same, they were fed at lib., during fattening on balance feed with the following components:

- Maize silage $6.00 \mathrm{~kg}$

- Maize grout. $2.80 \mathrm{~kg}$

- Dry sugar beet slices. $2.00 \mathrm{~kg}$

- Wheat straw. $1.20 \mathrm{~kg}$

- Soya grout. $1.10 \mathrm{~kg}$

- Wheat meal. $1.00 \mathrm{~kg}$
- Barley. $0.70 \mathrm{~kg}$

- Glutinated meal. $0.60 \mathrm{~kg}$

- Bovimix mineral premix. $0.20 \mathrm{~kg}$

- Saturated plant fat (dehydrated, grout consistence) $0.15 \mathrm{~kg}$

Body measurements were taken using the traditional method (stick and tape) described by Horn (1976), before slaughtering, together with weighing:

\section{b-Body and Ultrasound measurements}

Four body measurements are taken (1) height at withers, $\mathrm{cm}$ : distance between floor and highest point of withers, (2) hip height, $\mathrm{cm}$ : distance between floor and top of trochanter, (3) chest circumference, $\mathrm{cm}$ : in vertical level, behind scapula, and (4) diagonal body length, $\mathrm{cm}$ :distance between top of shoulders and isocheims. Two measurements of ultrasound are taken (1) Longissimus muscle area: between ribs 12 and 13 (Falco 100, Pie Medical equipment, linear head: $18 \mathrm{~cm}$, wave length: $3.5 \mathrm{MHz}$, depth: $23 \mathrm{~cm}$ ), and (2) P8, rump fat thickness, cm: at $3^{\text {rd }}$ lumbar vertebra, and the break-even point of normal drawn to the vertebral column and the line parallel with vertebral column from ischium; which means about one palm distance from vertebral column (Falco 100, Pie Medical equipment, linear head: $18 \mathrm{~cm}$, wave length: $3.5 \mathrm{MHz}$, depth: 5 $\mathrm{cm})$.

Experimental animals were slaughtered and boned at the same age in OSSARI slaughterhouse, Italy in the autumn of 2007. Live weight was measured at the fattening farm and at arrival at slaughterhouse as well. Slaughtering and boning was carried out according to the method proposed by ATK (Research Institute for Animal breeding and Nutrition at Herceghalom in Hungary). Carcasses were categorised by an official judge, according to EUROP-system (System of carcass qualification for musculaints and fatness in point). Both right and left carcasses were boned. Some characteristics of slaughtering and boning: warm carcass weight $(383.3 \mathrm{~kg})$, EUROP muscularity score (E: $n=2$, U: $n=24)$, EUROP fattiness score (2.38), lean meat $(305.6 \mathrm{~kg})$, bone $(47.2 \mathrm{~kg})$, fat $(21.1 \mathrm{~kg})$.

\section{Statistical analyses:}

Live weight of Charolais and Aubrac bulls fattened to the same age in the same environment did not differ statistically (38.278 $\mathrm{kg}, \mathrm{t}: 1.914$, df: 23.088, $\mathrm{P}=0.068, \alpha=0.05)$, so data of the two breeds were evaluated together. Means, standard deviations, coefficient of variability, sipmple correlation and stepwise regressions were evaluated using program SPSS 14.: basic statistics, correlation analysis. Stepwise regression analysis (backward method, entering condition $\mathrm{P}<0,05$, exiting 
condition $\mathrm{P}<0,10)$ was used to estimate effect of age $\left(\mathrm{x}_{1}\right)$, height at withers $\left(\mathrm{x}_{2}\right)$, hip height $\left(\mathrm{x}_{3}\right)$, chest circumference $\left(\mathrm{x}_{4}\right)$, diagonal body length $\left(\mathrm{x}_{5}\right), m$. longissimus dorsi area $\left(\mathrm{x}_{6}\right)$, and rump fat thickness $\left(\mathrm{x}_{7}\right)$ on round weight $(\mathrm{y})$. On other words, seven models of multiple regression to predict round weigh $(\mathrm{Y})$ was constructed, the first model includes all independent variables (x1, x2,........ and $\mathrm{x} 7)$, while one independent variable was omitted in each model.

\section{RESULTS AND DISCUSSION}

Means, standard deviations and coefficient of variability $(\mathrm{CV} \%)$ values for the measured traits of experimental animals are presented in Table 1. As in present experiment, Polgár et al. (2005) also fattened bulls to heavy weight, 550-600 kg. Red Angus F1 and R1 bulls were fattened to $615-\mathrm{kg}$ average weight, which is similar to results of present study. This weight was reached by an average age of 568 days, which is also just the same. However, results show a difference from the data published by Holló and Holló (2008) for Hungarian Simmental fattening bulls (age: 540 days, live weight: $580 \mathrm{~kg}$ ), and Herring et al. (1994) for Hereford fattening bulls (age: 500 days, live weight $534 \mathrm{~kg}$ ). In the two experiments mentioned before, carcass weights were 42-43 $\mathrm{kg}$ less than in present study. These examples show that it is very hard to find a publication that can be used for comparison, since circumstances are always different (breed, age, live weight, nutrition, etc.). Török et al. (2007) measured lower values for Rib eye area and P8 (Charolais and its crosses, REA: $82.3 \mathrm{~cm}^{2}$, P8: $0.46 \mathrm{~cm}$ ), than present data. The $\mathrm{CV} \%$ values for different traits studied are ranged from 1.12 $\%$ to $32.86 \%$. The present $\mathrm{CV} \%$ are lower than those reported by May et al. (2000) and ranged from 14.90 to 50.40 . The large CV \% value for rump fat thickness (P8, Table 1), reflect a great variation between fattening bulls in important beef trait. The different between the present means and those reported in other studies for fattening bulls raised in Hungarian bulls could due to one or more of the following (1) the herds were raised under different climatic and managerial conditions, (2) different herds could possibly be genetic and phenotypic different from other and (3) different methods and models of analysis were used.

Most publications reveal positive correlations between age and body measurements. As a practical use of this fact, Simmental breeders used chest circumference and body condition (low, average, high) to estimate live weight of animals (e.g. $200 \mathrm{~cm}$ chest circumference means $649 \mathrm{~kg}$ for an average-, $604 \mathrm{~kg}$ for a low, and $694 \mathrm{~kg}$ for a high-condition animal (Horn, 1976).

In the present experiment, correlations for live weight and body measurements $r=0.57$ $(\mathrm{P}<0.001)$ for height at withers, $\mathrm{r}=0.55$ $(\mathrm{P}<0.01)$ for hip height, $\mathrm{r}=0.60(\mathrm{P}<0.001)$ for chest circumference, and $\mathrm{r}=0.18$ for diagonal body length. In a Hungarian Aubrac herd, Szentléleki et al. (2005) calculated closer correlation values for $\mathrm{n}=54$ heifers (live weight - height at withers: $r=0.64$, live weight - hip height: $r=0.58$, live weight - chest circumference: $r=0.85$, live weight - diagonal body length: $\mathrm{r}=0.74, \mathrm{P}<0.05)$. Earlier results on weaned Charolais bull calves are also supporting the importance of taking body measurements (Tözsér et al. 2000). Using stepwise regression analysis, a common significant effect $(\mathrm{R}=0.94, \quad \mathrm{P}<0.001)$ of diagonal body weight $\left(\mathrm{x}_{1}\right)$ and chest circumference $\left(\mathrm{x}_{2}\right)$ on live weight was revealed. In this respect, Tozser et al. (1995) reported significant growth $(\mathrm{P}<0.001)$ in height at withers ( $10 \%)$, chest girth $(34 \% 0<$ chest width ( $15 \%$ ) and scrotum circumference (38 \%) of Charolais bulls $(n=40)$ during the 133 day long period of farm self performance test.

Correlations between body measurements and ultrasound measurements are presented in Table 2. Weak correlations were observed between age and body measurements (age height at withers: $r=0.05$, age - hip height: $r=$ -0.25 , age - chest circumference: $r=0.20$, age - diagonal body length: $r=-0.31$ ), which results are similar to those of Bene (2007), and Nagy et al. (2007). This can be explained by the fact that real age and the so-called biological age of animals were not the same. In this respect, Tozser et al. (2004) found no difference in estimated rib eye area of Charolais bulls (age 545 days) and heifers (age 540 days) reared under the same conditions (bull: $84.6 \mathrm{~cm} 2$; heifers: $80.2 \mathrm{~cm} 2$ ).

Body measurements showed weak or medium positive correlations to each other $(\mathrm{r}=$ 0.38-0.65, Table 2). Chest circumference showed the closest $(\mathrm{r}=0.62, \mathrm{P}<0.001)$, while diagonal body length the loosest correlation $(r=0.10)$ to round weight. Rib eye area correlated positively both to round weight $(\mathrm{r}=$ $0.35 ; \mathrm{P}<0.05)$, and chest circumference $(\mathrm{r}=$ 0.49 ; $\mathrm{P}<0.01$ ). These are no surprising results, considering the positive correlation between rib eye area and live weight (at least $\mathrm{r}=0.30$; Silva et al., 2003, Wolcott, 2003, Tőzsér et al., 2005 b, Török et al, 2008). The present results indicated that body measurements and Rib eye area, are indicator to round weight and selection fattening bulls according to body measurements, round weight will increase. In this respect, Tozser et al. (2004) calculated 
medium and close correlations between estimated rib eye area and slaughtering parameters of Hungarian Grey fattening bulls (meat, kg: experiment I, $\mathrm{r}=0.88, \mathrm{P}<0.05$; experiment II, $\mathrm{r}=0.66$ ).

Negative correlation coefficients were found between rump fat thickness (P8) and each of weight of round, age at slaughters, high height, chest circumference and rib eye area and being - 0.08, - 0.30, - 0.11, -0.16 and -0.22 , respectively (Table 2). The present results indicated that selection fattening bulls against lower rump fat thickness (P8) will increase weight of round and other body measurements. On the other hand, Torok et al. (2007) were the first in Hungary to calculate correlation between different subcutal fat thicknesses ( $\mathrm{P}$ 8 , rump fat, back fat) of $n=51$ fattening bulls of different genotypes ( Angus, Limousin, Hungarian Simmental, Charolais and Charolais $x$ Hungarian Simmental), found correlation P8 and rump fat thickness was $\mathrm{r}=0.93, \mathrm{P}<0.01$.

Characteristics of the different regression models are detailed in Tables $3 \& 4$. In Table 4, correlation coefficients (R) achieved at different steps and errors of estimation $\left(\mathrm{r}_{\mathrm{sxy}}\right)$ are introduced. In Model I, common effect of the 7 independent variables $\left(\mathrm{x}_{1}-\mathrm{x}_{7}\right)$ on round weight (y) was described by an R-value of $0.70(\mathrm{P}<0.10)$, with a standard error of 11.65 $\mathrm{kg}$ and $\mathrm{R}^{2}=0.48$. In Model III, age, height at withers, chest circumference, diagonal body length and longissimus muscle area were present as independent variables: $\mathrm{R}=0.69$, $(\mathrm{P}<0.05), \mathrm{r}_{\mathrm{sxy}}=11.08 \mathrm{~kg}$ and $\mathrm{R}^{2}=0.48$. Model IV contained age, height at withers, chest circumference and longissimus muscle area as independent variables, R-value $(0.69 ; \mathrm{P}<0.01)$ was the same, standard error $\left(\mathrm{r}_{\mathrm{sxy}}=10.88 \mathrm{~kg}\right)$ and $\mathrm{R}^{2}=0.48$ was similar to those calculated in case of Model III. The present results indicated the important of Rib eye area in the model and omitted these trait from the model reduced $\mathrm{R}^{2}$ from 0.49 to 0.38 . The last model was based only on chest circumference: $\mathrm{R}=0.62$ $(\mathrm{P}<0.001), \mathrm{r}_{\mathrm{sxy}}=11.11 \mathrm{~kg}$ and $\mathrm{R}^{2}=0.38$. This result implies that chest circumference alone determined round weight by 38 .

Data in Table 4 give information on changes of components in regression equations. It is interesting to pay attention to the growth of correlation coefficients with the different steps: e.g. chest circumference, Model I: $r=0.41$, Model VI: $r=0.51$. When choosing the optimal solution - in accordance with professional consideration - mainly two things must be evaluated in the same time: 1 . In which case is $\mathrm{R}$ the highest? 2. In which case is standard error of estimation the lowest? Considering these, among Models III and IV, Model IV seems to be the best to be applied, since determination coefficient is the same high as in Model III, while number of independent variables is less, and standard error of estimation is lower.

Change of multiple correlation coefficients was also examined when live weight was involved into the regression model as independent variable. Estimating round weight, $R$ value varied between 0.93-0.95 in the different models. These results can be explained partly with the close correlations with body measurements already reported before, and partly with the strong relation between live weight and round weight $(r=$ $0.93, \mathrm{P}<0.001)$. Theoretically, if aim was to work out regression equations for in vivo estimation of round weight, putting live weight into the models would increase determination coefficient $\left(\mathrm{R}^{2}\right)$. However the fact that animals of similar age are fattened to a given weight (e.g. $600 \mathrm{~kg}$ in case of great framed types) does not support the involvement of live weight into the model.

\section{CONCLUSION}

- It was proven by a multiple regression analysis that in beef bulls fattened to heavy weight, round weight was determined in $38 \%$ only by chest circumference.

- In vivo estimation of round weight is possible using data on age, height at withers, chest circumference and ultrasound measurement of longissimus muscle area: $\mathrm{R}=0.69, \mathrm{P}<0.01$, standard error of estimation $r_{s x y}=10.88 \mathrm{~kg}$. Inserting live weight into the model can theoretically increase reliability.

\section{REFERENCES}

Bartosiewicz L., T. Gere, I. Györkös and G. Radó, 1987. A növekedés szakaszossága üszőkben. Állattenyésztés

Takarmányozás, 36. 5: 425-432.

Bene Sz., 2007. Különböző fajtájú húshasznosítású tehenek néhány értékmérője azonos környezetben. Doktori értekezés, Keszthely.

Claus A., 1957. Die Messung natürlicher Grenzflachen in Schweinerkörper mit Ultraschall. Fleischwitsch, 9: 552-554.

Hassen, A., D.E. Wilson and G. H.Rouse, 1999. Evaluation od carcass, live and real time ultrasound measures in feedlot cattle: II. Effects of different age endpints on the accuracy of predicting the percentage of retail product, retail product weight, and hot carcass weight. J. of Anim. Sci. 77: 283-290.

Herring, W.O., D. C. Miller. J.K.Bertrand and L.L.Benyshek, 1994. Evaluation of machine, techician, and interpreter effects 
on ultrasonic measures of backfat and longissimus muscle area in beef cattle. J. Anim. Sci. 72: 2216-2226.

Holló G. 2001. A szarvasmarha testösszetételének és vágóértékének becslése digitális képalkotó eszközök (CT, MR) alkalmazásával. Doktori (Ph.D.) értekezés, Gödöllő.

Holló I., J. Tőzsér, G. Holló, R. Zándoki and I. Repa, 2005.: A képalkotó eljárások felhasználása a szarvasmarha húsirányú szelekciójában. Képalkotó eljárások jelentősége a XXI század állattenyésztésében. Budapest, MTA november 8, Állattenyésztés és Takarmányozás, 54..5: 480-493.

Holló I and G. Holló, 2008. Magyartarka hízóbikák húsminősége eltérő tömegtakarmány és arány, valamint lenmagdara kiegészítés esetén. XXXII. Óvári Tudományos Napok, október 2. (CD: 5 oldal).

Horn A. (szerk.) 1976. Szarvasmarhatenyésztés. Mezőgazdasági Kiadó, Budapest, 196-199.

Kovács A.Z., R. Papp, R. Zsoldos, R. Véghseö and M. Szabari, 2007. A kor és a termelés hatása red angus anyatehenek háti faggyú vastagságára. Acta Agraris Kaposváriensis, 11. 1. 9-21.

May, S.G., W. L. Miles, J. W. Edwards, J.J. Harris, J. B. Morgan, R. P. Garrett, F. L. Williams, J. W. Wise, H. R. Cross,H.R.and J. W. Savell, 2000. Using live estimates and ultrasound measurements to predict beef carcass cutability. J. of Anim. Sci. 78:1255-1261.

Miller, M.F., H. R. Cross, J. K. Baker and F. M. Buyers, 1988. Evaluation of live and carcass techniques for prediction beef carcass composition. Meat Sci. 23: 111129.

Nagy B., Sz. Bene, I. Bodó , I. and Szabó F. 2007. Magyar szürke bikák és tehenek élősúlya és testméretei. Állattenyésztés és takarmányozás, 56. 3: 195-203.

Polgár P. and F. Szabó, 1997. Sire effect on the body weight and measurements of Holstein-Friesian young bulls. J. Anim. Sci., Suppl. 1: 152.

Polgár P., Zs. Wagenhoffer, Zs. Grubics, Z. Hornyák, M. Török, Z. Lengyel and F. Szabó, 2005. Red angus F1 és R1 hízómarhák vágási és csontozási eredményeinek értékelése. Állattenyésztés és takarmányozás, 54.2 : 109-120.

Robinson, D.L., K. Hammond C. A. and Mcdonaldm 1993. Live animal measurement of carcass traits: estimation of genetic parameters of beef cattle. J. of Anim. Sci. 71: 1128-1135.
Silva, S.L., P/ R. Leme, S. M. Putrino, L. S. Martello, C. G. de Lima and D.P.D.Lanna, 2003. Prediction of carcass weight and dressing percentage in Nellore and Brangus young bulls by ultrasound measurements. Revista Brasileira de Zootecnia - Brazilian Journal of Animal Science, 32. 5. 1227-1235.

Szabó F. 1990. Adatok a magyar tarka és hereford szarvasmarhafajták reciprok keresztezéséröl. Állattenyésztés és Takarmányozás, 39. 2. 129-136.

Szabó F., P. Polgár, Cs. Szegleti and P. Arany 1993. Holstein-fríz bikák és tinók növekedése, vágóértéke és húsminősége. 1 . Közlemény: Növekedési tulajdonságok, hizlalási eredmények. Állattenyésztés és Takarmányozás, 42. 1. 15-23.

Szentléleki A., Z. Domokos, C. Bottura,, A. Massimiliano, R. Zándoki and J. Tőzsér, 2005. Elözetes adatok az aubrac szarvasmarhafajta testalakulásáról és vérmérsékletéről egy hazai tenyészetben. Állattenyésztés és Takarmányozás, 54. 6. 543-553.

Temple R.S., H. H. Stanker, D. Howry, G. Posakony, and H. H. Hazaleus, 1956. Ultrasonic and conductivity methodes for estimating fat thikness in live cattle. Am. Soc. Anim. Prod. West Section. Proc. 7. 477.

Török M., Kocsis Gy., Bene Sz., Kiss B., Farkas V. and Szabó F. 2007. Hízóbikák különböző testtájain ultrahanggal mért bőralatti faggyúvastagsága és azok összefüggései. Állattenyésztés és Takarmányozás, 56. 2. 117-124.

Török M., Gy. Kocsi and F. Szabó, 2008. Angus bikák bőr alatti faggyújának és rostélyos keresztmetszetének értékelése. Állattenyésztés és takarmányozás, 57. 2. 141-416.

Tőzsér J. 1991: Húshasznú tenyészbikajelöltek sajátteljesítmény-vizsgálati módszerének fejlesztése. Kandidátusi értekezés, MTA Budapest, Gödöllő, 73-79.

Tőzsér J., Z. Domokos, L. Alföldi , L. Sváb and L. Miliczki, 2000.: Charolais fajtájú választott bikaborjak testméretének és küllemi tulajdonságainak összefüggése. Állattenyésztés és Takarmányozás, 49. 4. 301-312.

Tőzsér J., Z. Domokos, Bujdosó M., Szentléleki A., Bakus G., Zándoki R. and Minorics R. 2004/b. Hosszú hátizom területének mérése real-time ultrahangkészülékkel a charolais fajtában. Acta Agraria Kaposváriensis, 8. 2.11-21.

Tőzsér J., Z. Domokos, M. Bujdosó and M. L. Wolcott, .2005/b. Szarvalt és szarvatlan charolais tenyészbikajelölteken a hosszú hátizom területének és a far bőr alatti 
faggyúvastagságának értékelése real-time ultrahangkészülékkel. Magyar Állatorvosok Lapja, 127. 3:131-138.

Tőzsér J., Z. Domokos, M. Mézes, K. Gerszi, P. Póti and A. Nagy. 1998. Charolais fajtájú választott bikaborjak típusának értékelése. Állattenyésztés és Takarmányozás, 47. 1:31-37.

Tőzsér J., G. Holló, I. Holló, J. Seregi and I. Repa, 2004/a. A szarvasmarha hosszú hátizom területének mérése real-time ultrahangkészülékkel. Állattenyésztés és Takarmányozás, 53. 6.:539-553.

Tőzsér J., R. Minorics, G. Bakus, A. Szentléleki, Z. Domokos, R. Zándoki and T. Kovács, 2005/a. A szarvasmarha hosszú hátizma területének mérése ultrahangképek alapján, kétféle módszerrel. a Hús, 1: 46-52.

Tözsér J., A. Nagy, K. Gerszi, M. Mézes , Z. Domokos, I. Kertész and T. Fekete, 1995. A herekörméret, a mellkasszélesség és mélység, valamint az élősúly fenotípusos összefüggésének változása az életkor függvényében charolais fajtájú tenyészbika-jelölteknél. Állattenyésztés és Takarmányozás, 3.:203-210.

Tőzsér J., A. Szentléleki, R. Zándoki, M. Sipos, G. Holló, I. Holló, Gy, Gábrielné
Tőzsér and K. Zsigmond, 2006. A fartájék bőr alatti faggyúvastagság (P8) mérésének megbízhatósága real-time ultrahangkészülékkel. Állattenyésztés és Takarmányozás, 55. 5: 451-457.

Waldner, D.N., M. E. Dikeman, R. R. Schalles, W. G. Olson, P. L. Houghton, J. A. Unruh and L. R. Corah, 1992. Validation of real time ultrasound equipment for prediction fat thickness, longissimus muscle areas and composition of Brangus bulls from 4 months to 2 years of age. J. Anim. Sci. 70: 3044-3054.

Wilson, D.E. 1992. Application of ultrasound for genetic improvement. J. Anim. Sci., 70. 3: 973-983.

Wilson, D.E, G. H. Rouse,, C. L. Haya. and A. Hassen, 2000. Carcass expected progeny differences using real-time ultrasound measures from developing Angus heifers. Ann. Meeting of ADSA-ASAS, July 24-28, Baltimore, Maryland, J. Anim. Sci. $78 "$ "suppl) 58.

Wolcott, M.L. 2003. The prediction of percent retail beef yield from live animal ultrasound measurements. Thesis of Master of Rural Sciences, The University of New England, Armidale, Australia, 126.

Table 1. Means, Standard deviations (SD) and coefficient of variability (CV \%) of age, body weight, body measurements and results of ultrasound measurements of the fattening bulls $(\mathbf{n}=\mathbf{2 6})$

\begin{tabular}{|c|c|c|c|}
\hline Traits & Mean & SD & CV \% \\
\hline Age at slaughter, day & 570 & 6.41 & 1.12 \\
\hline Live weight at slaughter, $\mathrm{kg}$ & 621 & 60.76 & 9.78 \\
\hline Height at withers, cm & 122.9 & 4.83 & 3.93 \\
\hline Hip height, cm & 130.5 & 3.61 & 2.77 \\
\hline Chest circumference, $\mathrm{cm}$ & 201.9 & 7.64 & 3.78 \\
\hline Diagonal body length, $\mathrm{cm}$ & 149.1 & 8.77 & 5.88 \\
\hline Rib eye area, REA, $\mathrm{cm}^{2}$ & 96.2 & 8.85 & 9.20 \\
\hline Rump fat thickness (P8), cm & 0.70 & 0.23 & 32.86 \\
\hline Weight of round, $\mathrm{kg}$ & 133.5 & 13.84 & 0.37 \\
\hline
\end{tabular}


Egyptian J. Anim. Prod. (2012)

Table 2. Correlation coefficients and significance levels between the examined traits

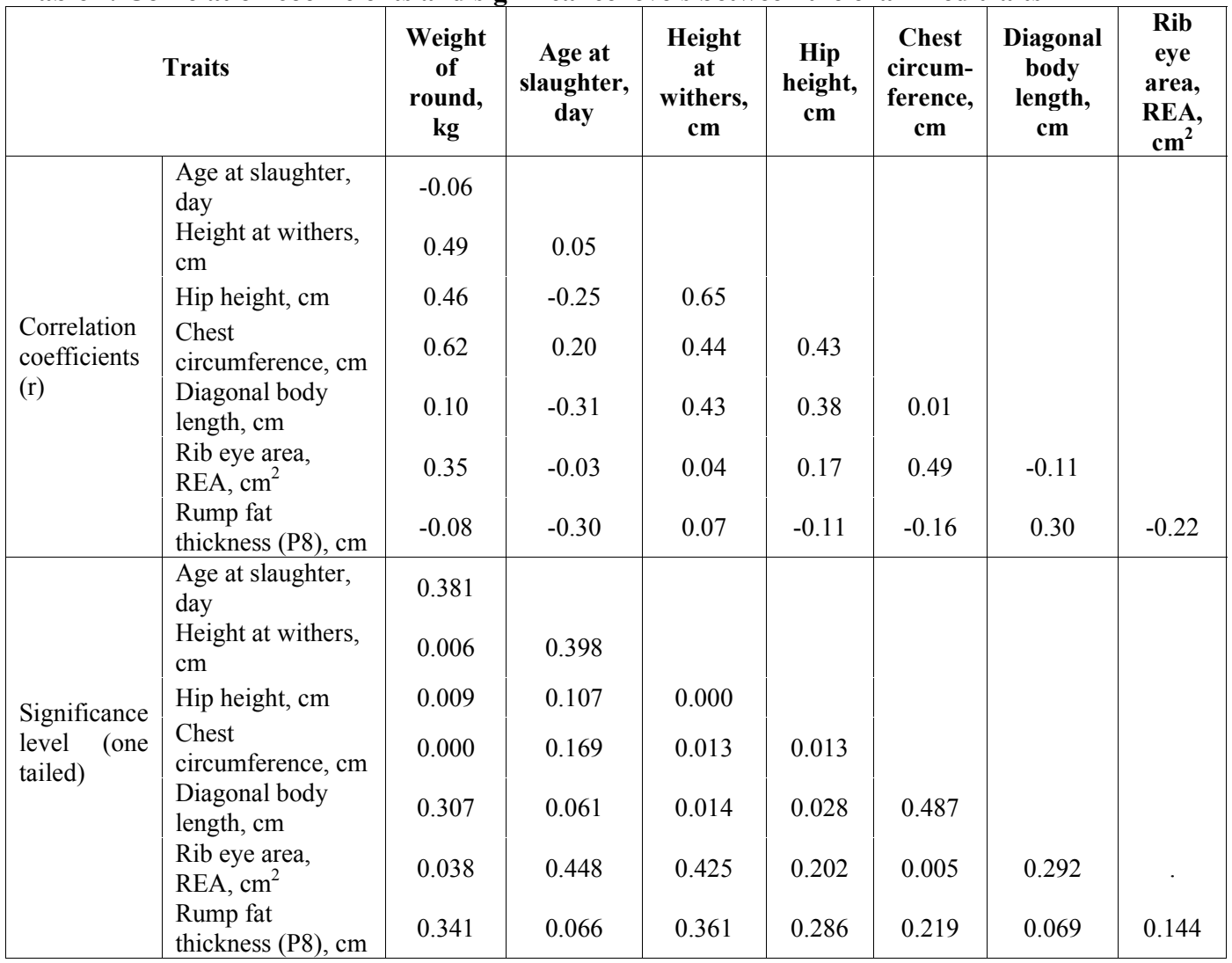

Table 3 Multiple correlation coefficients, determination coefficients and estimated standard error by models (backward stepwise)

\begin{tabular}{|c|c|c|c|}
\hline Models & $\begin{array}{c}\text { Multiple correlation } \\
\text { coefficient, } \mathbf{R}\end{array}$ & $\begin{array}{c}\text { Determination coefficient, } \\
\left(\mathbf{R}^{\mathbf{2}}\right)\end{array}$ & $\begin{array}{c}\text { Estimated standard } \\
\text { error, }\left(\mathbf{r}_{\mathbf{s x y}}\right)\end{array}$ \\
\hline 1 & $0.70^{*}$ & 0.49 & 11.65 \\
2 & $0.70^{* *}$ & 0.49 & 11.34 \\
3 & $0.69 * *$ & 0.48 & 11.08 \\
4 & $0.69 * * *$ & 0.48 & 10.88 \\
5 & $0.68^{* * *}$ & 0.47 & 10.71 \\
6 & $0.66^{* * * *}$ & 0.44 & 10.78 \\
$7^{\times}$ & $0.62 * * * *$ & 0.38 & 11.11 \\
\hline
\end{tabular}

$*=\mathrm{P}<0.10, * *=\mathrm{P}<0.05, * * *=\mathrm{P}<0.01, * * * *=\mathrm{P}<0.001$

${ }^{\times}=$simple correlation coefficient $(\mathrm{r})$ 


\section{تورستين' ، سزينتلك' ، دوماكس ، فرتين '، بوتارة" ، البرت و عادل صلاح خطاب؛

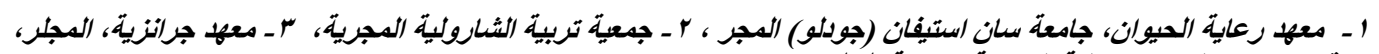

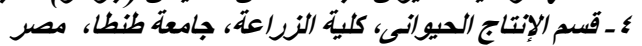

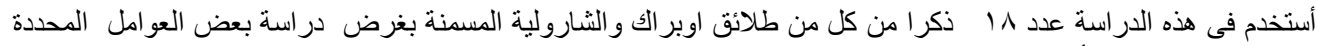

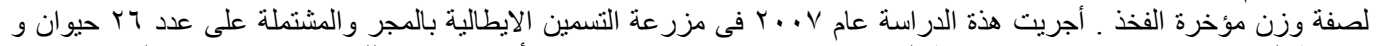

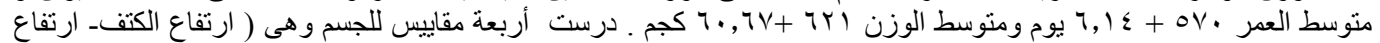

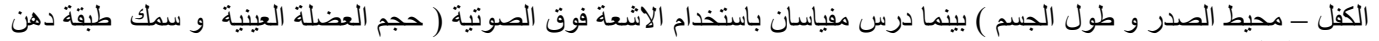
منطقة الكفل ).

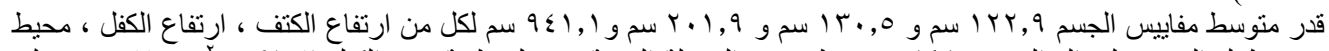

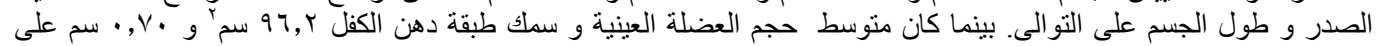

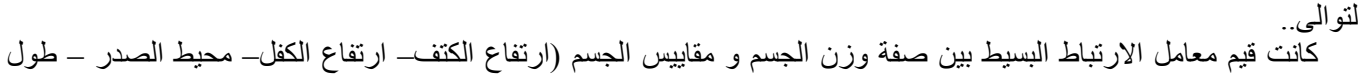

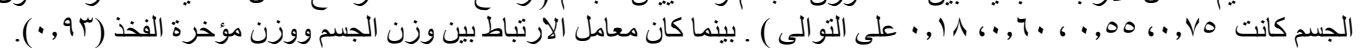

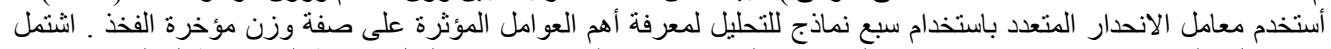

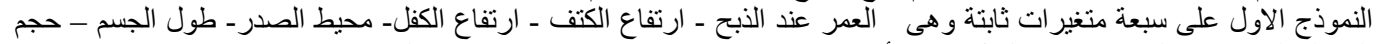

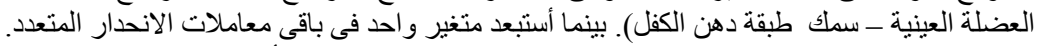

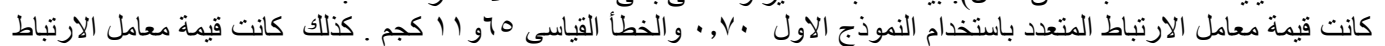

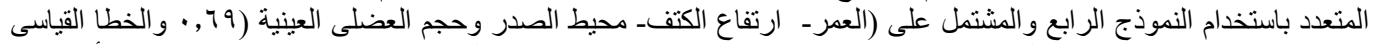

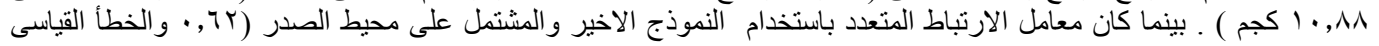

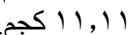
أوضخت تلك الر اسة أن محيط الصدر يؤثر بنسبة ^^\%\% ، وبذللك يجب الاهتمام ببعض النتغير ات مثل العمر وحجم العضلة العينية 